Volume 10 No. 2 September 2019

P-ISSN 2086-6178 E-ISSN 2579-3292

http://ejournal.bsi.ac.id/ejurnal/index.php/jkom

\title{
Analisis Semiotika Logo Diecast Hot Wheels Treasure Hunt
}

\author{
Jusuf Fadilah \\ Universitas Bina Sarana Informatika \\ jusuf.jff@bsi.ac.id
}

\begin{abstract}
Diecast Toys, better known as diecast names, are toys with an iron base and a combination of plastic, with many small scale fans. In general, diecast forms vary from cars, motorbikes, airplanes, bicycles, heavy equipment (vehicles and tools surrounding the mine) and others are some form variants currently available. One of the famous diecast brands is Hot Wheels, where there are special and rarely found editions which are often referred to as Hot Wheels Treasure Hunt, the differentiator of which is the Treasure Hunt mark / logos in the blister and better raw materials. In this study, we will analyze the Hot Wheels Treasure Hunt logo with Roland Barthes's semiotic method, this study found three aspects of meaning contained in Roland Barthes's semiotic analysis method wherein the denotative meaning the researchers found in general collectors could find a very different appearance of the Hot Wheels Treasure Hunt with regular Hot Wheel, seen from the logo found on the blister and striking color difference. Whereas from the connotation meaning researchers found collectors felt very fortunate to be able to find the Hot Wheels Treasure Hunt if hunting because of the hot wheels Treasure Hunt series was made specifically and special. And from the mythical meaning researchers found collectors will feel addicted when hunting certain models included in the T-Hunt and Treasure Hunt series, and make it an investment. Because in general when transacted between collectors, then a 1-year-old car costs a minimum of $2 x$ the original price, which is why some collectors make it an investment.
\end{abstract}

Keywords: Semiotics, Logo, Treasure Hunt.

Cara Sitasi: Fadilah Jusuf . Analisis Semiotika Logo Diecast Hot Wheels Treasure Hunt. Jurnal Komunikasi 10(2), 139-144.

\section{PENDAHULUAN}

Mainan anak-anak pasti semua orang pernah memlikinya atau sekedar memainkannya. Dari yang paling sederhana dan murah, hingga yang kompleks dan mahal. Akan tetapi hal tersebut tidak menjadi masalah selama yang menggunakan atau memiliki mainan tersebut merasa senang dan terhibur. Berbagai merk dan jenis yang ada di pasaran membuat penggemar atau kolektor baik itu anak maupun orang dewasa bebas dalam memilih mainan yang akan dibeli atau bahkan dikoleksi.

Diecast Toys yang lebih dikenal dengan nama diecast yaitu mainan dengan bahan dasar besi dan gabungan plastik, berskala kecil memang banyak penggemarnya. Secara umum, bentuk diecast bermacam-macam mulai dari mobil, sepeda motor, pesawat terbang, sepeda, alat berat (kendaraan dan alat-alat seputar tambang) dan yang lainnya adalah beberapa varian bentuk yang saat ini tersedia. Mulai dari usia kanak-kanak, remaja hingga yang sudah berumur pun banyak yang gemar untuk mengkoleksi mainan tersebut, yang sekarang ini dapat ditemui hampir dimana-mana. Bagi para kolektor diecast, tidak jarang yang mengawali hobi ini justru pada saat mereka sudah remaja dan beranjak dewasa. Alasan sentimentil akan masa kecil, kegemaran pada industri otomotif, fanatisme pada suatu merk tertentu dan berbagai latar belakang, para kolektor rela menyisihkan tidak sedikit uang untuk sebuah hobi yang tak mengenal usia, gender dan latar belakang. Salah satu diecast yang terkenal di indonesia bermerk Hot Wheels, kita bisa menemukan mainan diecast tersebut dengan mudah dimana saja saat ini baik di mal, supermarket, maupun toserba sekitar rumah.

Logo merupakan simbol khusus yang menjadi ikon dari event atau suatu perusahaan sebagai ciri khas. Logo juga disebut dengan tanda nonverbal, yakni berupa tanda yang berupa anggota badan, lalau diikuti dengan lambang, suara, misalnya bersiul atau membunyikan ssst.... yang bermakna memanggil seseorang ,tanda yang diciptakan manusia untuk menghemat waktu, tenaga, dan menjaga kerahasiaan, misalnya rambu-rambu lalu lintas, bendera, tiupan terompet dan benda-benda yang bermakna kultural dan ritual. (Sobur, 2013)

Logo merupakan sebuah visi untuk menyampaikan citra positif melalui sebuah tampilan sederhana melalui tampilan logo, selain itu logo juga harus divisualisasikan seimbang dan enak dipandang, serta relevan sehingga mampu dijelaskan mengenai apa yang ditawarkan, atau makna apa yang ingin di sampaikan melalui logo tersebut. 
Menurut Roland Barthnes bahasa adalah sebuah sistem tanda yang mencerminkan asumsi-asumsi dari suatu masyarakat tertentu dalam waktu tertentu. (Sobur, 2013)

Semiotika adalah salah satu ilmu yang mempelajari makna atau arti dari suatu tanda atau lambang. Yang menjadi dasar tentang semiotika adalah konsep tentang tanda, tak hanya bahasa dan sistem komunikasi yang tersusun oleh tanda-tanda. (Sobur, 2013)

Salah satu tanda yang menarik untuk dibahas oleh peneliti salah satunya yaitu tanda/logo Treasure Hunt pada Blister dan body yang dibuat oleh diecast Hot Wheels, banyak para kolektor diecast yang tidak segan bahkan rela menghabiskan waktu dan biaya hanya untuk mendapatkan Hot Wheels berlogo Treasure Hunt, maka dari itu penelitian ini akan membahas tentang Analisis Semiotika Logo Diecast Hot Wheels Treasure Hunt.

"Asal kata logo berasal dari bahasa Yunani logos, yang berarti kata, pikiran, pembicaraan, akal budi. Pada awalnya yang lebih dulu populer adalah istilah logotype, bukan logo". (Rustan, 2017)

Berikut ini jenis-jenis logo menurut John Murphy dan Michael Rowe, yaitu:

a) Name Only Logo

logo ini diambil dari sebuah nama dengan menggunakan gaya grafis yang khusus. Logo ini memberi kesan ketegasan dan pesan secara langsung kepada masyarakat. Contohnya logo pada produk elektronik.

\section{b) Name atau Symbol Logo}

Kelebihan dari logo ini adalah bentuknya yang ringkas dan fleksibel karena jenis logo ini mampu berdiri sendiri.

c) Initial Letter Logo

Logo ini biasanya digunakan untuk nama produk atau organisasi sebagai komponen. Logo jenis ini biasanya menunjukkan rangkaian dari pemilik perusahaan contohnya logo bank.

d) Pictorial Names Logo

Logo yang menggunakan nama produk atau organisasi sebagai komponen penting dari gaya logo, yang secara keseluruhan logo ini memiliki gaya yang sangat khusus. Contohnya coca cola, McDonald, dan lain-lain.

e) Associative logo

Logo ini biasanya berdiri bebas tanpa membuat nama produk atau perusahaan, tetapi memiliki asosiasi langsung dengan nama, produk, atau wilayah aktifitasnya.

f) Allusive Logo

Logo jenis ini memilki hubungan yang tidak langsung antara nama dengan logonya sehingga jenis logo ini sulit untuk dipahami.

g) Abstract logo
Yang dimaksud dari jenis logo ini adalah logo dapat menimbulkan berbagai kesan, yang dipengaruhi oleh daya pemahaman masyarakat. Ini terjadi karena bentuk visual logo ini sangat abstrak. Contoh adalah logo bakrie Brothers. kekurangan dari logo ini adalah bentuknya yang tidak jelas, sehingga sangat sulit dipahami oleh masyarakat. (Perdana, 2007)

Logo mempunyai fungsi-fungsi yang sangat penting bagi sebuah perusahaan atau organisasi. Menurut Sudiana fungsi logo yaitu:

a) Identitas suatu produk, atau organisasi

b) Yang membedakan dari organisasi lain

c) Media komunikasi yang menyampaikan mengenai pesan

d) Sebagai nilai tambahan (menimbulkan gengsi misalnya)

e) Pertanda adanya sesuatu yang dilindungi hukum. (Anggoro, 2007)

Seperti yang dikatan oleh Susane K.Langer: "salah satu kebutuhan pokok manusia adalah kebutuhan simbolis atau penggunaan lambang, diaman manusia adalah satu-satunya hewan yang menggunakan lambang". (Mulyana, 2008)

Peran simbol visual sangat penting sebagai alat berkomnikasi dan sangat tidak terbatas dalam kehidupan sehari-hari. Logo merupakansisi dari identitas perusahaan atau organisasi yang disusun sebagai alat memebedakan untuk dikenali masyarakat.

Semiotika merupakan suatu ilmu atau metode analisis untuk mengkaji tanda (Sobur, 2013). Model analisis semiotika menurut Charles S. Peirce semiotika berangakt dari tiga elemen utama yang disebut peirce teori segita makna atau triangel meaning.

Dijelaskan sebagai berikut:

a. Lambang

Suatu tanda dimana tanda dan acuannya merupakan hubungan yang sudah terbentuk secara konvensional. Lambang ini adalah tanda yang dibentuk karena adanya consensus dari pengguna tanda.

b. Ikon

Suatu tanda dimana tanda dan acuannya berupa hubungan kemiripan. Jadi ikon adalah bentuk tanda yang dalam berbagai bentuk menyerupai objek dari tanda tersebut.

c. Indeks

Merupakan tanda dan acuannya timbul karena kedekatan eksustensi. Jadi indeks merupakan hubungan langsung (kausalitas) dengan objeknya.

Semiotika model Roland Barthes mengembangkan teori semiotika dari Saussure yang merupakan perancang pertama sebuah model sistematis dengan model ini. Inti dari teori Barthes adalah ide tentang dua tatanan signifikasi (Orders of signification), Barthes menggunakan denotasi, konotasi, dan mitos. (Kriyanto, 2006) 


\section{METODE PENELITIAN \\ Metode Pengumpulan Data}

"Teknik pengumpulan data merupakan langkah yang paling strategis dalam penelitian, karena tujuan utama dari peelitian adalah mendapatkan data". (Sugiyono, 2014)

Maka dari itu, dalam penelitian ini peneliti melakukan pengumpulan data melalui beberapa metode, yaitu:

\section{a. Observasi}

Menurut Hadi, "observasi merupakan suatu proses yang kompleks, suatu proses yang tersusun dari berbagai proses biologis dan psikhologis. Dua di antara yang terpenting adalah proses-proses pengamatan dan ingatan”. (Sugiyono, 2014)

Dalam metode ini, peneliti mengamati segala sesuatu yang berhubungan dengan diecast Hot Whels Treasure Hunt baik dengan cara hunting maupun berkunjung ke komunitas diecast.

\section{b. Dokumentasi / Kepustakaan}

Dokumen merupakan catatan peristiwa yang sudah berlalu. Dokumen bisa berbentuk tulisan, gambar, atau karya-karya monumental dari seorang. Dokumen yang berbentuk tulisan misalnya catatan harian, sejarah kehidupan (life histories), ceritera, biografi, peraturan, kebijakan. Dokumen yang berbentuk gambar misalnya foto, gambar hidup, sketsa dan lain-lain. Dokumen yang berbentuk karya misalnya karya seni, yang dapat berupa gambar, patung, film dan lain-lain. Studi dokumen merupakan pelengkap dari penggunan metode observasi dan wawancara dalam penelitian kualitatif. (Sugiyono, 2014)

Riset pustaka sekaligus memanfaatkan sumber perpustakaan untuk memperoleh data penelitiannya. Tegasnya riset pustaka membatasi kegiatannya hanya pada bahan-bahan koleksi perpustakaan saja tanpa memerlukan riset lapangan. (Zed, 2014)

Dalam metode ini peneliti mendokumentasikan gambar atau foto yang berhubungan dengan diecast Hot Wheels Treasure Hunt, serta mengumpulkan informasi yang dibutuhkan melalui buku-buku yang ada di perpustakaan maupun milik pribadi, serta beberapa artikel mengenai Hot Wheels Treasure Hunt yang ada di internet sebagai referensi dalam penelitian ini.

\section{Analisis Kualitatif}

Metode penelitian kualitatif adalah metode penelitian yang berlandaskan pada filsafat postpositivisme, digunakan untuk meneliti pada kondisi obyek yang alamiah, (sebagai lawannya adalah eksperimen) dimana peneliti adalah sebagai instrumen kunci, teknik pengumpulan data dilakukan secara triangulasi (gabungan), analisis data bersifat induktif/kualitatif, dan hasil penelitian kualitatif lebih menekankan makna dari pada generalisasi. (Sugiyono, 2014)

Peneliti mengumpulkan serta mengolah data dan informasi yang berbentuk gambar atau tulisan yang didapat dari hasil wawancara, dokumentasi pribadi dan juga referensi yang didapat dari buku, artikel dan sumber-sumber pendukung yang ada di internet.

\section{Analisis Semiotika Roland Barthes}

Semiotika model Roland Barthes merupakan pengembangan dari semiotika Sessuare, inti dari teori ini adalah ide tentang dua tatanan signifikasi (Orders of signification), berikut adalah penjelasan tentang Denotasi, Konotasi, dan Mitos:

a. Denotasi

Merujuk pada apa yang diyakini akal sehat manusia. (common-sense), makna yang teramati dari sebuah tanda.

b. Konotasi

Menjelaskan tentang interaksi yang terjadi ketika tanda-tanda bertemu dengan perasaan atau emosi dari pengguna dan nilai-nilai dalam kebudayaan.

c. Mitos

Mitos merupakan sebuah cerita dimana suatu kebudayaan menjelaskna beberapa aspek dari realitas atau alam bagi orang yang mempercayainya. Mitos primitif yang berkaitan dengan kehidupan dan kematian, manusia dan Tuhan, baik dan buruk. Mitos terkini adalah soal maskulinitas, feminitas, tentang keluarga, tentang ilmu pengetahuan.

Barthes menyebut denotasi adalah makna yang nyata dari tanda sedangkan konotasi merupakan istilah untuk menunjukkan signifikandari tahap kedua. (Fiske, 2012)

\section{HASIL DAN PEMBAHASAN}

Treasure Hunt (kadang disebut juga T-Hunt) adalah sebuah brand dari mobil-mobil Hot Wheels yang diperkenalkan oleh Mattel pada tahun 1995. Terdiri dari 12 mobil setiap tahunnya; yang dirilis per bulan. Bisa ada 12 atau $15 \mathrm{~T}$ Hunts. Produksi asli yang berjalan dimulai pada 10.000 buah di seluruh dunia, dan telah berkembang karena permintaan dan meningkatnya popularitas mengoleksi Hot Wheels. Pada tahun 2007, 157 Treasure Hunts telah dirilis.

Hot Wheels Treasure Hunt diidentifikasi oleh label pada kemasannya. Pada kartu blister akan tertera "Treasure Hunt" atau "T-Hunt" pada green bar, dengan ilustrasi peti harta karun. Mobil-mobilnya dihiasi dengan desain mencolok. Hot Wheels Treasure Hunt memiliki harga pasar sekunder tinggi ketika pertama kali dirilis. Nilainya biasanya stabil ketika banyak mobil-mobil yang tersedia di pasar. Kadang-kadang kolektor akan melihat ini sebagai menurunnya harga mobil, tetapi, data empiris sangat menyatakan lain. Sebaliknya, harga tinggi yang pada 
awalnya terlihat adalah hasil dari "booming internet". Ketika hanya ada beberapa mobil baru yang tersedia di pasar, dan ratusan kolektor mencarinya, harganya akan meroket. Data yang dikumpulkan selama dua belas tahun terakhir benar-benar menunjukkan harga Treasure Hunts pada umumnya meningkat cukup baik. Harga dari Internet umumnya jauh lebih tinggi, karena sering ketika kolektor memberikan nilainya, mereka tidak memperhitungkan biaya pengiriman, risiko, dan ketidaknyamanan karena semua faktor negatif di pasar online.

Pada tahun 2007, Mattel memperkenalkan sistem Treasure Hunt dua tingkat. Sebuah Treasure Hunt reguler akan menampilkan cat enamel normal dan roda yang normal, dibandingkan dengan mobil Hot Wheels lainnya. Produksi ini dikabarkan lebih besar dari Treasure Hunts pada masa sebelumnya. Super Treasure Hunts lebih jarang, dan seperti Treasure Hunts pada masa sebelumnya, Super Treasure Hunts menampilkan Real Riders wheels dan Spectraflame paint. Semua 12 mobil Treasure Hunt direncanakan akan dirilis dalam versi reguler dan super.

Berbagai macam jenis mobil Treasure Hunt sudah diluncurkan oleh Mattel, produsen Hot Wheels, ke pasaran sejak tahun 1995. Hingga sekarang, seri Treasure Hunt masih menjadi idaman para kolektor Hot Wheels. Seri Hot Wheels yang diproduksi terbatas dan sulit dicari ini memiliki nilai jual yang tinggi.

Namun, untuk mengenali seri Treasure Hunt saat ini makin sulit. Pasalnya, kini kemasannya tak lagi menuliskan "Treasure Hunt" sebagai identifikasinya. Kolektor harus jeli dengan memperhatikan keberadaan logo Treasure Hunt berupa lingkaran dengan api di dalamnya atau adanya inisial "TH" pada badan mobil.

Sebenarnya, sebelum mulai adanya logo Treasure Hunt, mobil seri Treasure Hunt memiliki keunikan pada kemasan yang membuatnya mudah diidentifikasi yaitu adanya garis warna hijau bertuliskan "Treasure Hunt". Kemudian kemasan mengalami beberapa kali perubahan desain.

Tahun 1995 hingga 2000, terdapat garis horisontal warna hijau bertuliskan "Treasure Hunt" sebagai identitas bahwa mobil tersebut termasuk dalam seri Treasure Hunt.
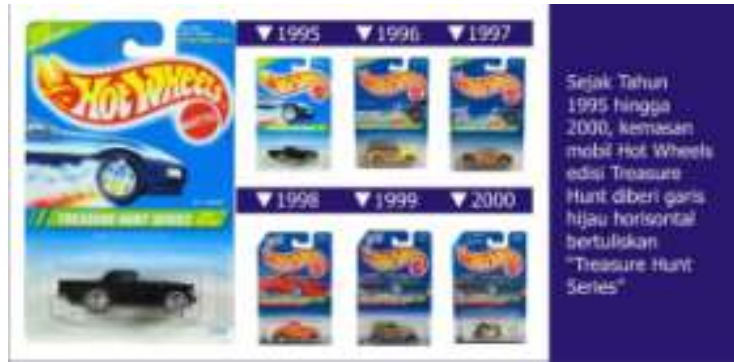

Gambar 1. Logo Hot Wheels Treasure Hunt Mulai Tahun 1995 hingga 2000

Sejak tahun 2001, garis hijau tak lagi horisontal, tetapi menjadi vertikal kecil di samping bawah kemasan dengan tulisan "T-Hunt". Desain berubah lagi pada tahun 2007. Garis vertikal hijau melintang di sisi samping kemasan dengan tulisan "Treasure Hunt”. Mulai tahun 2007 juga , Super Treasure Hunt diluncurkan.

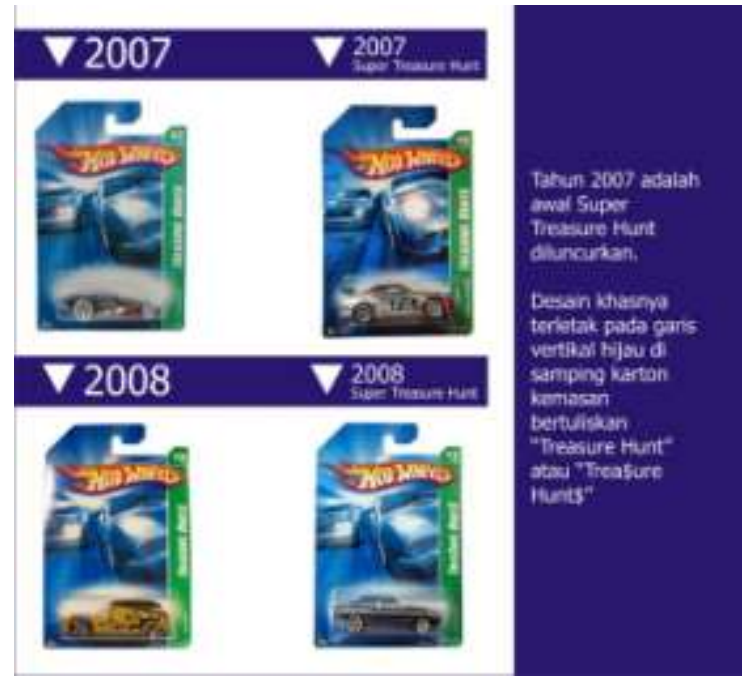

Gambar 2. Logo Hot Wheels Treasure Hunt Mulai Tahun 2007

Tahun 2009, garis hijau vertikal masih dipertahankan. Tetapi, tulisan "Treasure Hunt" dibuat lebih kecil dan diletakkan di samping bawah kemasan. Sementara itu, pada garis hijau bertuliskan tipe mobilnya.

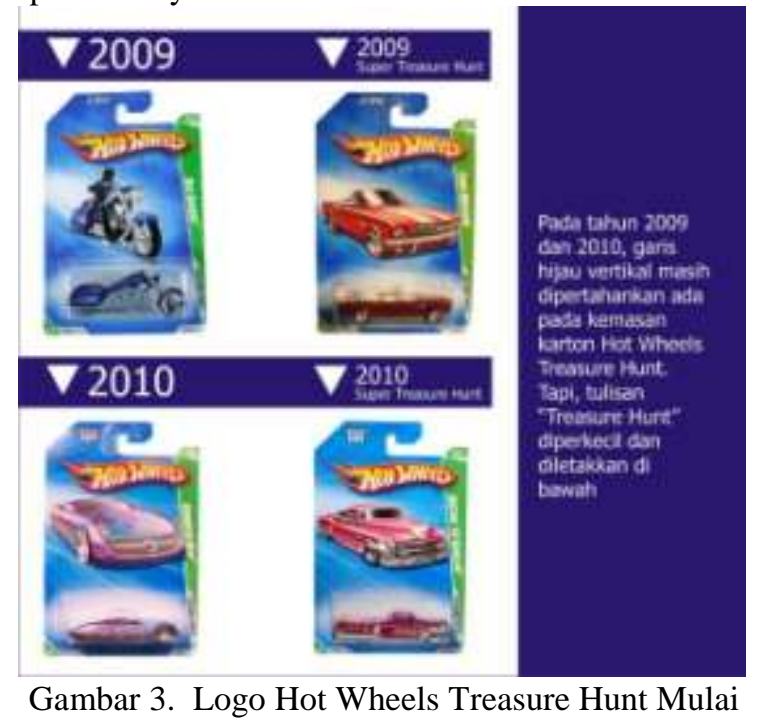

Tahun 2009

Garis hijau vertikal masih ada namun lebih pendek sejak tahun 2012. Garis tersebut bertuliskan tipe mobil. Tulisan "Treasure Hunt" dibuat sangat kecil dan diletakkan di bawah mobil. 


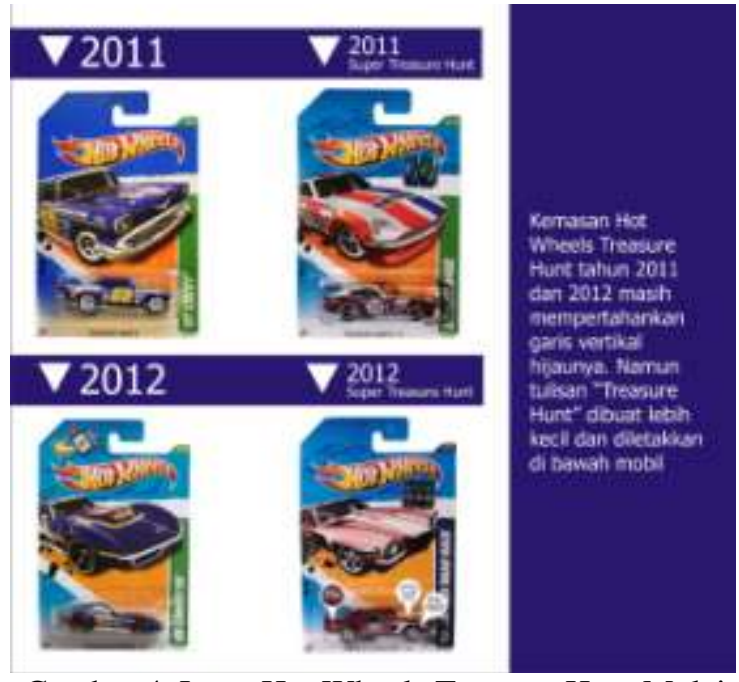

Gambar 4. Logo Hot Wheels Treasure Hunt Mulai Tahun 2011

Mulai tahun 2013, tulisan "Treasure Hunt" pada kemasan dihapuskan diganti dengan inisial "TH" atau logo seri Treasure Hunt berupa lingkaran dengan gambar api di dalamnya. Logo dan inisial tersebut dicetak langsung pada badan mobil.

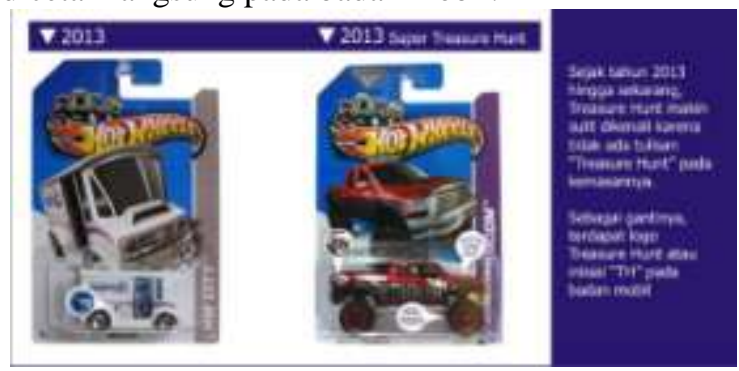

Gambar 5. Logo Hot Wheels Treasure Hunt Mulai Tahun 2013

\section{Analisis Semiotika Roland Barthes}

Semiotika model Roland Barthes merupakan pengembangan dari semiotika Sessuare, inti dari teori ini adalah ide tentang dua tatanan signifikasi (Orders of signification), dari hasil temuan yang telah dijelaskan sebelumnya berikut adalah penjelasan tentang hasil analisis logo Hot Wheels Trasure Hunt dari aspek Denotasi, Konotasi, dan Mitos:

a. Denotasi

Makna denotasi yang ditemukan dalam penelitian ini yaitu kolektor mengetahui akan perbedaan Hot Wheels biasa (Regular) dengan Treasure Hunt dilihat dari logo yang terdapat pada blister dan perbedaan warna yang mencolok. Pada umumnya penampakkannya yang sangat berbeda dengan Hot Wheel biasa. Untuk cat mobilnya mempunyai ciri cat atau warna mobil yang cenderung lebih gelap, mempunyai ban atau roda berbahan karet. Untuk Hot Wheels TH seri 2018 ini mempunyai ciri logo Bola Api berwarna Emas pada blister, dan logo TH pada body mobil.

b. Konotasi
Makna Konotasi yang ditemukan dalam penelitian ini yaitu kolektor akan merasakan emosi yang bergejolak di dada dan merasa senang karena Hot Wheels Super Treasure Hunt atau yang biasa disebut dengan TH\$, TH Super, ataupun Hot Wheels Ban Karet, ini ialah versi dari hot wheels series yang dibuat khusus dan special. Karena tidak banyak dibuat, maka hanya beberapa kolektor saja yang sangat beruntung dapat menemukannya jika hunting. Karena hanya di buat terbatas, maka harganya pun sangat mahal jika untuk dijual lagi bagi kolektor.

c. Mitos

Makna Mitos yang ditemukan dalam penelitian ini yaitu kolektor akan merasa ketagihan pada saat hunting model-model tertentu yang termasuk dalam seri T-Hunt dan Treasure Hunt. Seri TH memiliki keunggulan yaitu produksinya yang dibatasi dan keistimewaan pada produknya, baik itu cat khusus, model khusus atau bahkan yang memiliki ban karet. Yang terakhir bisa dibilang yang paling istimewa dan paling mahal, terutama jika yang menjual mengerti tentang Hot Wheels. Dasi hasil observasi peneliti, peneliti pernah menemukan TH dengan ban karet dijual Rp. 150.000,- di salah satu pusat perbelanjaan, disalah satu situs bahkan ada yang menawarkan enam model HW dengan ban karet seharga satu juta rupiah.

Treasure Hunt adalah koleksi limited edition (langka) dari seri Hotwheels. Sebenarnya harganya hanya Rp.29.900, Namun jika model diecast tertentu sedang naik daun dan menjadi incaran para kolektor, harganya bisa menjadi ratusan ribu, jutaan, bahkan puluhan juta. Diecast yang menjadi merchandise di event tertentu juga pasti bisa menjadi melambung harganya. Pada acara IDE (Indonesia Diecast Expo) 2017 yang lalu, sebuah merchandise diecast morris mini dengan nomor punggung 1 terjual dalam lelang seharga 32 juta rupiah.

Pada dasarnya seluruh mobil hotwheels edisi 2002 akan menjadi barang langka di tahun 2003, karena di tahun 2003 mobil edisi 2002 tidak diproduksi lagi. Dengan demikian mobil edisi 2002 tipe apapun tentu harganya akan lebih tinggi di tahun 2003. Pada umumnya bila ditransaksikan antar kolektor, maka mobil yg berusia 1 tahun harganya minimal $2 \mathrm{X}$ lipat dari harga aslinya, karena itulah sebagian kolektor menjadikannya sebagai investasi.

\section{KESIMPULAN \\ Kesimpulan}

Setelah melakukan proses penelitian ini, peneliti menemukan tiga aspek makna yang terdapat dalam metode analisis semiotika Roland Barthes dimana dalam makna denotasi peneliti menemukan pada umumnya kolektor dapat mengetahui penampakkan Hot Wheels Treasure Hunt yang sangat berbeda dengan Hot Wheel biasa (regular) dilihat dari logo yang terdapat pada blister dan perbedaan warna yang 
mencolok. Sedangkan dari makna konotasi peneliti menemukan kolektor merasa sangat beruntung dapat menemukan Hot Wheels Treasure Hunt ketika hunting karena Hot Wheels Treasure Hunt series dibuat khusus dan special. Dan dari makna mitos peneliti menemukan kolektor akan merasa ketagihan pada saat hunting model-model tertentu yang termasuk dalam seri T-Hunt dan Treasure Hunt, dan menjadikannya sebagai investasi. Sebab pada umumnya bila ditransaksikan antar kolektor, maka mobil yg berusia 1 tahun harganya minimal $2 \mathrm{X}$ lipat dari harga aslinya, karena itulah sebagian kolektor menjadikannya sebagai investasi

\section{Saran}

Saran-saran yang dapat diberikan peneliti kepada diecast Hot Wheels Treasure Hunt:

1. Melanjutkan strategi penjualan dengan cara menjual Hot Wheels Treasure Hunt dengan desain yang special.

2. Lebih gencar mempromosikan iklan Hot Wheels baik regular dan Treasure Hunt agar semakin banyak masyarakat yang mengetahui dan teracuni mainan diecast ini.

3. Membuat bahan baku yang lebih baik lagi untuk jenis-jenis Hot Wheels yang special agar bisa terus dijadikan investasi yang baik untuk masa mendatang.

\section{REFERENSI}

Anggoro, M. T. (2007). Metode Penelitian. Jakarta: Universitas Terbuka.

Fiske, J. (2012). Pengantar Ilmu Komunikasi. Jakarta: PT Rajagrafindo Persada.
Kriyanto, R. (2006). Teknik Praktis Riset Komunikasi: Disertai Contoh Praktis Riset Media, Public Relations, Advertising, Komunikasi Organisasi, Komunikasi Pemasaran. Jakarta: Kencana Prenada Media Group.

Mulyana, D. (2008). Ilmu Komunikasi: Suatu Pengantar. Bandung: Rosdakarya.

Perdana, D. (2007). Company Profile Radio Citra Suhada. Skripsi, Fakultas Desain, Desain Komunikasi Visual. Bandung.

Rustan, S. (2017). Mendesain LOGO (3rd editio). Jakarta: Gramedia Pustaka Utama.

Sobur, D. A. (2013). Semiotika Komunikasi. Bandung: PT Remaja Rosdakarya.

Sugiyono. (2014). Metode Penelitian Kuantitatif, Kualitatif Dan $R \& D$ (22nd editi). Bandung: CV Alfabeta.

Zed, M. (2014). Metode Penelitian Kepustakaan (3rd Editio). Jakarta: Yayasan Pustaka Obor Indonesia.

\section{PROFIL PENULIS :}

Jusuf Fadilah aktif sebagai Akademisi di Universitas Bina Sarana Informatika sebagai dosen teori dan juga instruktur labolatorium di Program Studi Periklanan Fakultas Komunikasi dan Bahasa Universitas Bina Sarana Informatika.

Kritik dan saran sangat diharapkan guna peningkatan kualitas dan penulisan selanjutnya. 